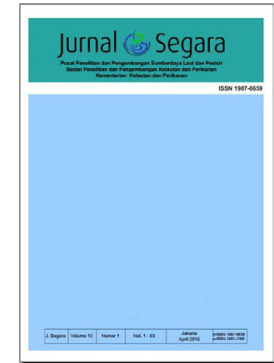

JURNAL SEGARA

http://ejournal-balitbang.kkp.go.id/index.php/segara

ISSN : 1907-0659

e-ISSN : 2461-1166

Accreditation Number: 766/AU3/P2MI-LIPI/10/2016

\title{
THE SUITABILITY OF COASTAL AREA DEVELOPMENT BASED ON MINAWISATACONCEPTIN PACITAN DISTRICT
}

\author{
Syahrial Nur Amri \& Taslim Arifin
}

\author{
Marine Research Center, The Agency for Marine \& Fisheries Reseach \& Human Resources, \\ Indonesian Ministry of Marine Affairs \& Fisheries \\ Received: 15 November 2015; Revised: 19 May 2017; Accepted: 30 July 2017
}

\begin{abstract}
Minawisata concept is the implementation and integration of efforts to optimize the utilization of marine and coastal resources with action to maintain the sustainability and value of sustainability. This study aimed to determine the suitability of the coastal land development in Pacitan District based on the potential of marine and coastal areas in accordance to the minawisata concept. Study area covered 7 (seven) districts along the coastline of Pacitan District, East Java Province, namely Donorejo, Pringkuku, Pacitan, Kebonagung, Tulakan, Ngadirejo, and Sudimoro District. The methodology used in this study is a combination of Geographic Information Systems analysis, satellite imagery interpretation, and field data processing. This study is limited to the identification of the potential of marine and coastal area, the suitability of land use, and the suitability of coastal area development based on the minawisata concept. The results show that there are three dominant utilizations of marine and coastal areas in Pacitan District, including: Marine Aquaculture, Capture Fisheries, and Beach Tourism. Based on the analysis on suitability of the marine and coastal area, seven districts in Pacitan are suitable for fisheries and beach tourism, while only two districts were suitable for marine aquaculture with several conditions, namely Pacitan District and Ngadirejo District. The implementation of minawisata concept for coastal area suitability based on the analysis of 7 (seven) identified districts is feasible for further development.
\end{abstract}

Keywords: land suitability, coastal area development, minawisata concept, Pacitan

\section{INTRODUCTION}

The coastal region is the area with the most populous concentration of people inhabited by humans and the venue for various development activities (Dahuri, 1998; Masalu, 2008). The concentration of human life development and the various development of human life and the various developments in the region is due to three strong economic reasons, namely that coastal areas are productive areas on earth, coastal areas provide convenience for various activities as well as coastal areas have attractive charms for objects tourism (Dahuri, 1998; Riyadi, 2004).

Indonesia has the potential of natural beauty and cultural richness of high value in the ecotourism industry market. These natural potentials can be biological resources and their ecosystems, the diversity of flora, fauna and natural phenomena with the beauty of scenery (Emma \& Mardiana, 2014; Ihsan et al., 2015). In the marine sector, Indonesia has biological resources and non biological resources such as marine services, fisheries, marine mining, maritime industry, and marine transportation. The sector can be one of Indonesia's mainstay ecotourism (Eka et al., 2016).

The management and utilization of fishery resources basically has the purpose to improve the welfare of the community, especially the fishermen community and also other communities living in coastal areas (Sudirman et al., 2012). Fandeli (2000); META (2002) classifies tours based on the concept of utilization, namely Nature Tourism, Cultural Tourism and Ecotourism (Ecotourism, Green Tourism, Altenatif Tourism). Especially for ecotourism, in ecotourism there is a form of natural resource utilization and

Corresponding author:

Jl. Pasir Putih I Ancol Timur, Jakarta Utara 14430. Email: sn_amri@yahoo.co.id 
environmental services by human known as marine ecotourism.

In the fisheries business system, Mina is often used to replace the word Fishery which essentially contains the same meaning with the word fishery it self, whereas Tourism is a form of exploiting natural resources that rely on nature services for human satisfaction (Sudirman et al., 2012). Minawisata is the utilization of tourism area with the development of fishery production to reach the interest of the user community of fishery development in the tourism area (Sudirman et al., 2012; Wiadnya, 2011). Minawisata is the utilization of tourist area with the development of fishery production to reach the interest of the user community of fishery development in the tourist area (Kamal, 2005).

Based on the Indonesian Minister of Marine Affairs and Fisheries Decre No. 32/2010, concerning with the determination of Minapolitan regions, Pacitan is listed as the District in East Java province that is designated as a minapolitan development area. Thus, in-depth study to up hold the program is required. This study is intended to identify the biophysical condition of the coastal area, socio-economic conditions of the local community, availability and provision of facilities and infrastructure, regulations and related institutions. The identification would be followed by the assessment of the suitability of the coastal area development based on the potential of marine and coastal areas, and the assessment of the suitability between land utilization and land development based on minawisata.

\section{METHODOLOGY}

\section{Time and Study Area}

The study was conducted in 2011 with area covering the coast line of Pacitan District, which included 7 (seven) districts namely: Donorejo, Pringkuku, Pacitan, Kebonagung, Tulakan, Ngadirejo, and Sudimoro (Fig. 1).

\section{Data Processing and Analysis}

To determine the suitability of land for the benefit of minawisata in coastal area of Pacitan District, conducted through (Figure 2):

1. Identification of land suitability based on biophysical parameters, analyzed through satellite image interpretation (Sebayang, 2002; Loppies, 2010) and analysis of geographic information systems (Saputra \& Yulmaini, 2012; Rangka \& Paena, 2012; Yulius et al., 2013). Calculate the biophysical weight of land suitability through the land suitability matrix for the benefit of minawisata. In the case of Pacitan District, the analysis focused on two forms of utilization, namely as a coastal tourist destination and the cultivation of natural seaweeds and ponds.

2. Direct identification and observation related to coastal community habit in research location in utilizing the coastal resources.

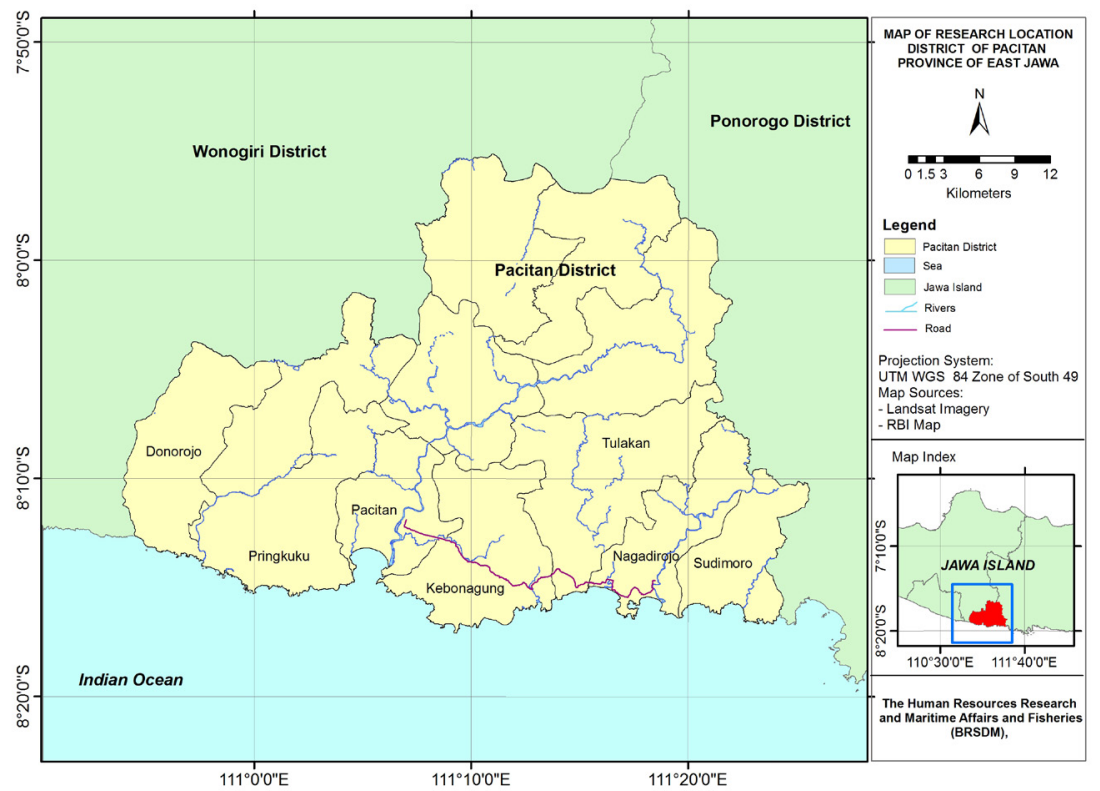

Figure 1. Study Site Map (Source: The results of TM Landsat Satellite Imagery Processing and Administrative Map of Pacitan). 


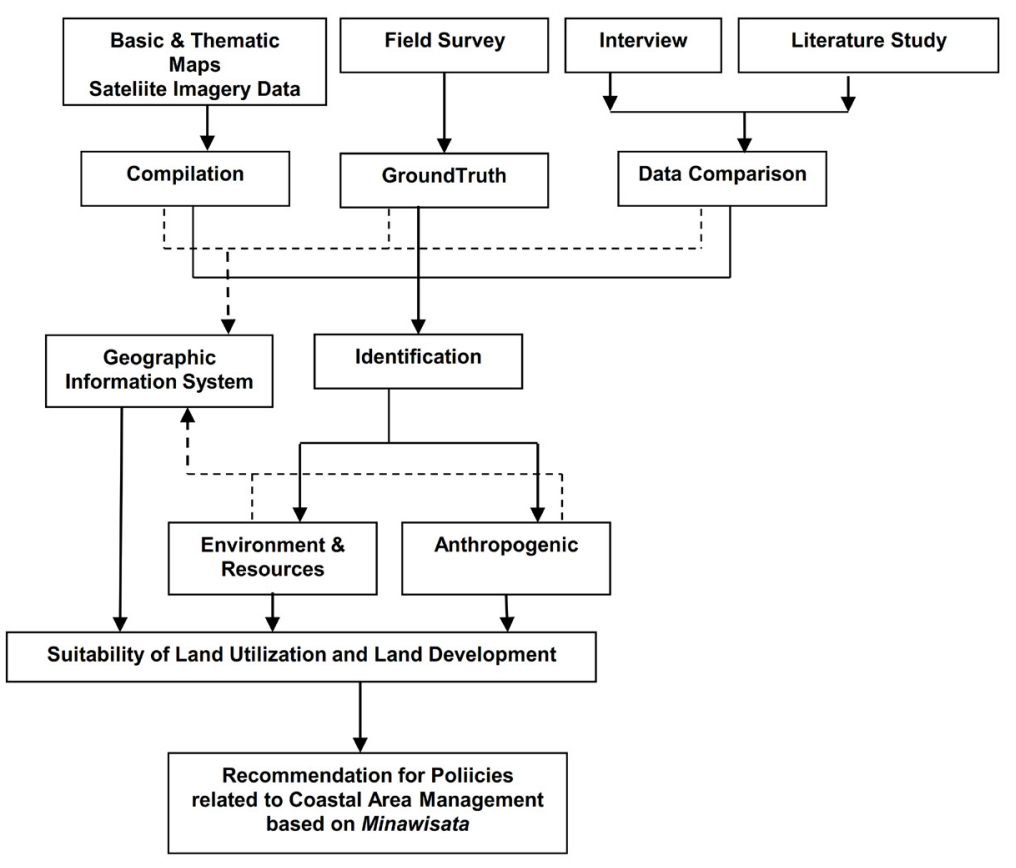

Figure 2. Research Framework.

3. Adjusting to local government policies in utilizing and managing the coastal areas.

\section{The Matrix of the Land Suitability}

Minawisata development location is based on the analysis of land suitability of coastal areas by using the suitability matrix for the utilization of minawisata fishing line, seaweed cultivation, and coastal tourism. The conformity matrix for land use is presented in Tables 1 to 3 .

In this study, suitability classes were divided into two classes, namely the suitable and not suitable, defined as follows:

Class S: Suitable, which indicated the absence of serious limited factors or insignificant effect on the area development, or there was limited factor but could be managed by alternative technology.

Class N: Not Suitable, which indicated the existence of permanent limited factor that prevented any possible development in the area.

The weight and value of each parameter in a specific designation produced a score of certain parameter in a designation. Total score of each parameter in a designation was the total score of a

Table 1.

Criteria of land suitability for capture fisheries area development

\begin{tabular}{|c|c|c|c|c|c|c|}
\hline \multirow{2}{*}{ No } & \multirow{2}{*}{ Parameter } & \multicolumn{4}{|c|}{ Score } & \multirow{2}{*}{$\begin{array}{l}\text { Total } \\
\text { Score }\end{array}$} \\
\hline & & 1 & 3 & 5 & 7 & \\
\hline 1 & Waters depth $(\mathrm{m})$ & $<3$ & $3-5$ & $5-10$ & $>10$ & 2 \\
\hline 2 & Topography & Sloping & Less sloping & Sloping-steep & Steep & 2 \\
\hline 3 & Light intensity $(\mathrm{m})$ & $<5$ & $5-8$ & $8-10$ & $>10$ & 1 \\
\hline 4 & Weather changes & Frequent & Moderate & Infrequent & None & 2 \\
\hline 5 & Coral reef status & Poor & Moderate & Good & Very good & 2 \\
\hline 6 & Pollution source & Many & Moderate & A few & None & 1 \\
\hline 7 & $\begin{array}{l}\text { Abundance of target } \\
\text { fish (ind } / 350 \mathrm{~m} \text { ) }\end{array}$ & $<100$ & $100-150$ & $150-200$ & $>200$ & 2 \\
\hline
\end{tabular}

Feasibility Evaluation :

$12 \%-114 \%$ : Suitable

$<12 \quad$ : Not Suitable 
Table 2. Matrix of Land Suitability for Seaweed Cultivation Development

\begin{tabular}{|c|c|c|c|c|c|c|}
\hline \multirow{2}{*}{ No. } & \multirow{2}{*}{ Parameter } & \multicolumn{2}{|c|}{ Land suitability level } & \multirow{2}{*}{ Limited value } & \multirow{2}{*}{ Weight } & \multirow{2}{*}{ Score } \\
\hline & & Suitable & Not suitable & & & \\
\hline 1. & Temperature $\left({ }^{\circ} \mathrm{C}\right)$ & $26-33$ & $<26$ or $>33$ & $\begin{array}{l}\text { Suitable }: 2 \\
\text { Not suitable : } 1\end{array}$ & 0.1 & $\begin{array}{l}0.2 \\
0.1\end{array}$ \\
\hline 2. & Salinity $\left(\%{ }_{00}\right)$ & $15-38$ & $<15$ or $>38$ & $\begin{array}{ll}\text { Suitable } & : 2 \\
\text { Not suitable }: 1\end{array}$ & 0.09 & $\begin{array}{l}0.18 \\
0.09\end{array}$ \\
\hline 3. & Tide height $(\mathrm{m})$ & $0.5-3.5$ & $<0.5$ or $>3.5$ & $\begin{array}{ll}\text { Suitable } & : 2 \\
\text { Not suitable }: 1\end{array}$ & 0.09 & $\begin{array}{l}0.18 \\
0.09\end{array}$ \\
\hline 4. & Current velocity $(\mathrm{m} / \mathrm{s})$ & $0.1-0.4$ & $<0.1$ or $>0.4$ & $\begin{array}{ll}\text { Suitable } & : 2 \\
\text { Not suitable }: 1\end{array}$ & 0.1 & $\begin{array}{l}0.2 \\
0.1\end{array}$ \\
\hline 5. & Light intensity (m) & $0.3-0.6$ & $<0.30$ & $\begin{array}{ll}\text { Suitable } & : 2 \\
\text { Not suitable }: 1\end{array}$ & 0.1 & $\begin{array}{l}0.2 \\
0.1\end{array}$ \\
\hline 6 & Depth $(m)$ & $0.3-2.1$ & $<0.3$ or $>2.1$ & $\begin{array}{ll}\text { Suitable } & : 2 \\
\text { Not suitable }: 1\end{array}$ & 0.09 & $\begin{array}{l}0.18 \\
0.09\end{array}$ \\
\hline 7. & Wave height $(\mathrm{m})$ & $0.1-0.4$ & $<0.1$ or $>0.4$ & $\begin{array}{ll}\text { Suitable } & : 2 \\
\text { Not suitable }: 1\end{array}$ & 0.1 & $\begin{array}{l}0.2 \\
0.1\end{array}$ \\
\hline 8. & Turbidity (NTU) & $0.1-40$ & $>40$ & $\begin{array}{ll}\text { Suitable } & : 2 \\
\text { Not suitable }: 1\end{array}$ & 0.1 & $\begin{array}{l}0.2 \\
0.1\end{array}$ \\
\hline
\end{tabular}

Source: Djurdjani (1999), Aslan (1998), Sulistijo et al. (1996), Utojo et al. (2000), Hidayat (1994) (Modification and re-processing).

Table 3. Matrix of Land Suitability for Beach Tourism Development

\begin{tabular}{|c|c|c|c|c|c|c|}
\hline No & Parameter & & ted value & & Weight & Score \\
\hline 1 & Current velocity $(\mathrm{cm} / \mathrm{s})$ & $\begin{array}{l}\text { Slow } \\
\text { Moderate } \\
\text { Fast }\end{array}$ & $\begin{array}{l}<0.4 \\
0.4-1.0 \\
>1.0\end{array}$ & $\begin{array}{l}3 \\
2 \\
1\end{array}$ & 0.3 & $\begin{array}{l}0.9 \\
0.6 \\
0.3\end{array}$ \\
\hline 2 & Substrates (mm) & $\begin{array}{l}\text { Sand } \\
\text { Rock } \\
\text { Mud }\end{array}$ & $\begin{array}{l}0.0625-2 \\
>2 \\
>0.0625\end{array}$ & $\begin{array}{l}3 \\
2 \\
1\end{array}$ & 0.2 & $\begin{array}{l}0.6 \\
0.4 \\
0.2\end{array}$ \\
\hline 3 & Wave (m) & $\begin{array}{l}\text { Low } \\
\text { Moderate } \\
\text { High }\end{array}$ & $\begin{array}{l}<0,20 \\
0.21-0.50 \\
>0.50\end{array}$ & $\begin{array}{l}3 \\
2 \\
3\end{array}$ & 0.2 & $\begin{array}{l}0.6 \\
0.4 \\
0.2\end{array}$ \\
\hline 4 & Depth (m) & $\begin{array}{l}\text { Ideal } \\
\text { Moderate } \\
\text { Not ideal }\end{array}$ & $\begin{array}{l}0-3 \\
3-5 \\
>5\end{array}$ & $\begin{array}{l}3 \\
2 \\
1\end{array}$ & 0.1 & $\begin{array}{l}0.3 \\
0.2 \\
0.1\end{array}$ \\
\hline 5 & Tidal range $(\mathrm{m})$ & $\begin{array}{l}\text { Low } \\
\text { Moderate } \\
\text { High }\end{array}$ & $\begin{array}{l}<1 \\
1-3 \\
>3\end{array}$ & $\begin{array}{l}3 \\
2 \\
1\end{array}$ & 0.1 & $\begin{array}{l}0.3 \\
0.2 \\
0.1\end{array}$ \\
\hline 6 & Slope (\%) & $\begin{array}{l}\text { Flat } \\
\text { Sloping } \\
\text { Steep }\end{array}$ & $\begin{array}{l}0-2 \\
3-7 \\
>8\end{array}$ & $\begin{array}{l}3 \\
2 \\
1\end{array}$ & 0.1 & $\begin{array}{l}0.3 \\
0.2 \\
0.1\end{array}$ \\
\hline
\end{tabular}

Source: Anonymous (1991), Djurjani (1998), and Nontji (1994).

Feasibility Evaluation :

$50 \%-100 \%$ : Suitable

$<50 \% \quad$ : Not Suitable (Asmawi, 1990). 
specific designation. Total score was formulated as follows:

Total score $\beta=\sum_{\alpha=0}^{n}($ weight $\alpha \times$ score $/$ value $\alpha)$

where:

$\begin{array}{ll}\text { Total score } \beta= & \text { Total score of each parameter in } \\ & \text { designation } \beta, \\ \alpha & \text { Parameter/criteria of } \alpha \\ & \text { designation } \beta, \\ \mathrm{n} & \begin{array}{l}\text { Total parameter/criteria } \\ \text { of designation } \beta .\end{array}\end{array}$

Total score was used to determine the suitability classes. Suitability classes of coastal area development for a designation had a range/interval depending on the number of suitability class, total score of the maximum, and total score of the minimum of a designation.

The interval of land suitability classes for a designation is calculated by using the following formula:

$\left.\operatorname{RK} \beta=\frac{\text { Max Total Score } \beta-\text { Min Total Score } \beta}{\text { Total classes } \beta} \ldots \ldots \ldots \ldots . . .2\right)$

where:

RK $\beta$

Max $\beta$ total score

Min $\beta$ total score

Total class $\beta$

\section{RESULTS AND DISCUSSION}

In a strategic perspective, the development of minawisata becomes to the realization of the utilization of natural resources and environmental services that are conserved and it can serve as pillars of sustainable development of marine, coastal and small islands. Therefore, the main objective of the Minawisata concept is conserving the ecosystems and natural resources, so that ecological processes in an ecosystem can continue and sustain the utilization of coastal, marine and small island coastal resources and services for sustainable fisheries and tourism (Sudirman et al., 2012).

\section{Potential of Coastal Area for Utilization and Development}

The quality of Pacitan waters is ideal for the life of marine biota, especially economically important marine species. South Coast path, in fact, has numbers of upwelling spots throughout the year thus the region provides abundant pelagic fish commodities and the South Coast Sea is also a migration path of pelagic fishat the same time. In 2010, Indonesian Ministry of Marine Affairs and Fisheries recorded the potential production of the coastline in Pacitan was high amounted to 1,335.13 tons per year. Nevertheless, this potential should be explored and utilized effectively to meet the livelihood of local communities in the coastline, but without overlooking the resources sustainability.

The quality of Pacitan waters is actually ideal for seaweed cultivation. Based on data obtained from Agency of Marine and Fisheries of Pacitan District in 2010 , the production of seaweed was 1,032 tons or approximately amounted to Rp.3,096 billion. However, the physical condition of the waters is relatively extreme for the development of seaweed cultivation. It said that the wave characteristics in Pacitan District have the height of coming waves $(\mathrm{H} 0)$ reaches 4.8 meters approximately and wave period ( $\mathrm{T}$ ) 10.8 seconds with dominant coming direction from southeast and South (DJPT,2005). Clearly, alternative technology is required to address the obstruction, despite the needs for considerable cost both for technical issues and human resource capacity. Fig. 3 demonstrates the map of the potential areas for capture fisheries and aquaculture based on district in Pacitan District. The map shows that each district on the coast of Pacitan has potential for the development of fishery activities.

As an archipelagic country, coastal tourism plays an important role for the national economy, as long as its management is good for maintaining environmental quality and attracting tourists (Silva et al., 2007; Akrom et al., 2015). Uncontrolled tourism development will have an impact on resource and environmental damage. Therefore, it is important to control the number of visitors or the carrying capacity of the beach, because the development of coastal tourism activities such as marine tourism is not mass tourism, easily damaged, and the space for visitors is very limited (Ketjulan, 2010; Akrom et al., 2015). Based on data obtained from the Tourism Office of Pacitan District in 2012 , as many as 654,641 of domestic and foreign tourists visited Pacitan Area. It increased by $42.43 \%$ in compared to the number of tourists in 2011 of 376,862 visitors. Domestic tourists in 2012 were 654,099 visitors in which there was an increase of $42.41 \%$ in compared 


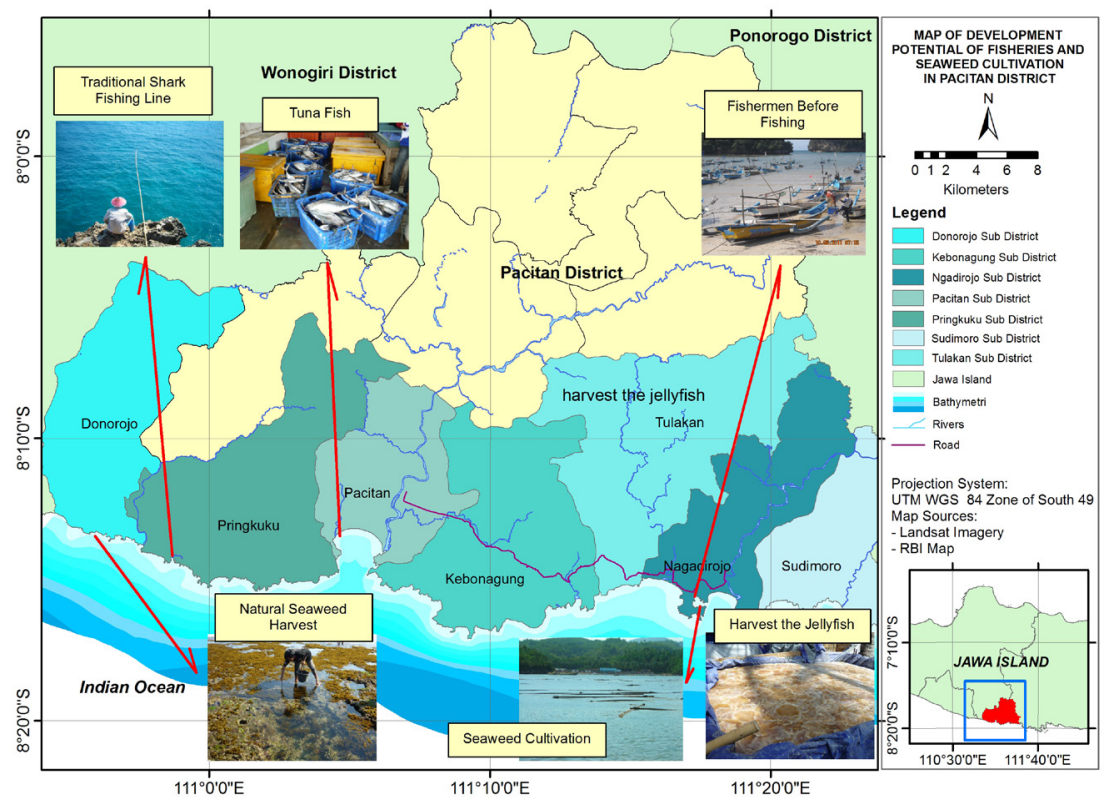

Figure 3. Map of Prospective Coastal Areas for Capture Fisheries and Seaweed Cultivation in Pacitan District.

to the number of tourists in 2011 of 376,705 visitors. Foreign tourist arrival was also augmented significantly, approximately $71.03 \%$, from 157 in 2011 to 542 tourists in 2012.

Pacitan beach that stretches along the southern part of Java Coast is $70.709 \mathrm{~km}$ in length and covers seven districts in Pacitan Districtis out standing for its natural beauty. The geological and geomorphologic conditions of Pacitan coastline are the combination of white sand beach and igneous rocks, which is aesthetically exotic and stunning. In addition, its extreme oceanography of wave heights in the range of 1.3 to 2.5 meters is definitely ideal for surfing. Fig. 4 illustrated prospective coastal areas for beach tourism activities.

\section{The Land Suitability of Coastal Area Development of Pacitan District}

Analysis on the sustainability of coastal area development in Pacitan District based on the

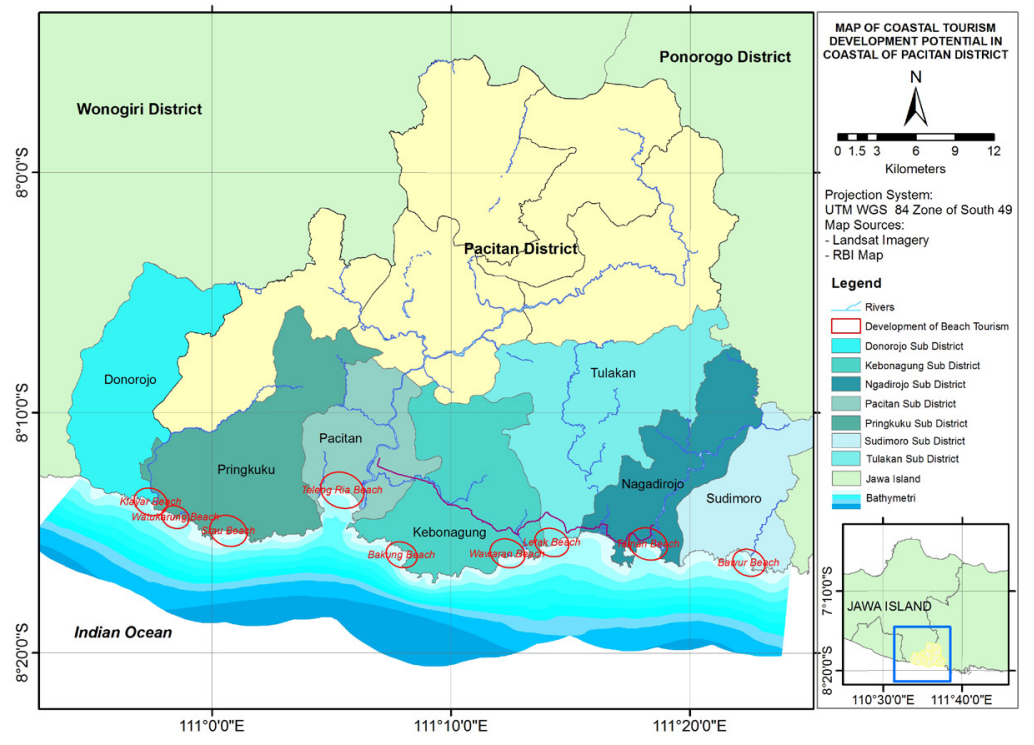

Figure 4. Map of Prospective Beaches for Tourism Development in Pacitan District. 
Table 4

The Land Suitability of Coastal Area Development in Pacitan District

\begin{tabular}{|c|c|c|c|c|}
\hline \multirow{2}{*}{ No. } & \multirow{2}{*}{ District } & \multicolumn{3}{|c|}{ Suitability status } \\
\hline & & Beach tourism & Seaweed cultivation & Capture fisheries \\
\hline 1 & Donorejo & Suitable & Not suitable & Suitable \\
\hline 2 & Pringkuku & Suitable & Not suitable & Suitable \\
\hline 3 & Pacitan & Suitable & Suitable* & Suitable \\
\hline 4 & Kebonagung & Suitable & Not suitable & Suitable \\
\hline 5 & Tulakan & Suitable & Not suitable & Suitable \\
\hline 6 & Ngadirejo & Suitable & Suitable ** & Suitable \\
\hline 7 & Sudimoro & Suitable & Not suitable & Suitable \\
\hline
\end{tabular}

Description:

* In Pacitan bay, seaweed cultivation is not enclosed in Regional Spatial Plan (RTRW), even though it might be effortable based on land suitability. However, seaweed cultivation in embankment is developed in Tamperan estuary and Pancer (Grindulu) estuary.

**Specifically for seaweed cultivation, the main suitability was relied on ecology and water quality parameters, meanwhile, physical oceanography and geomorphology parameters required environmental engineering.

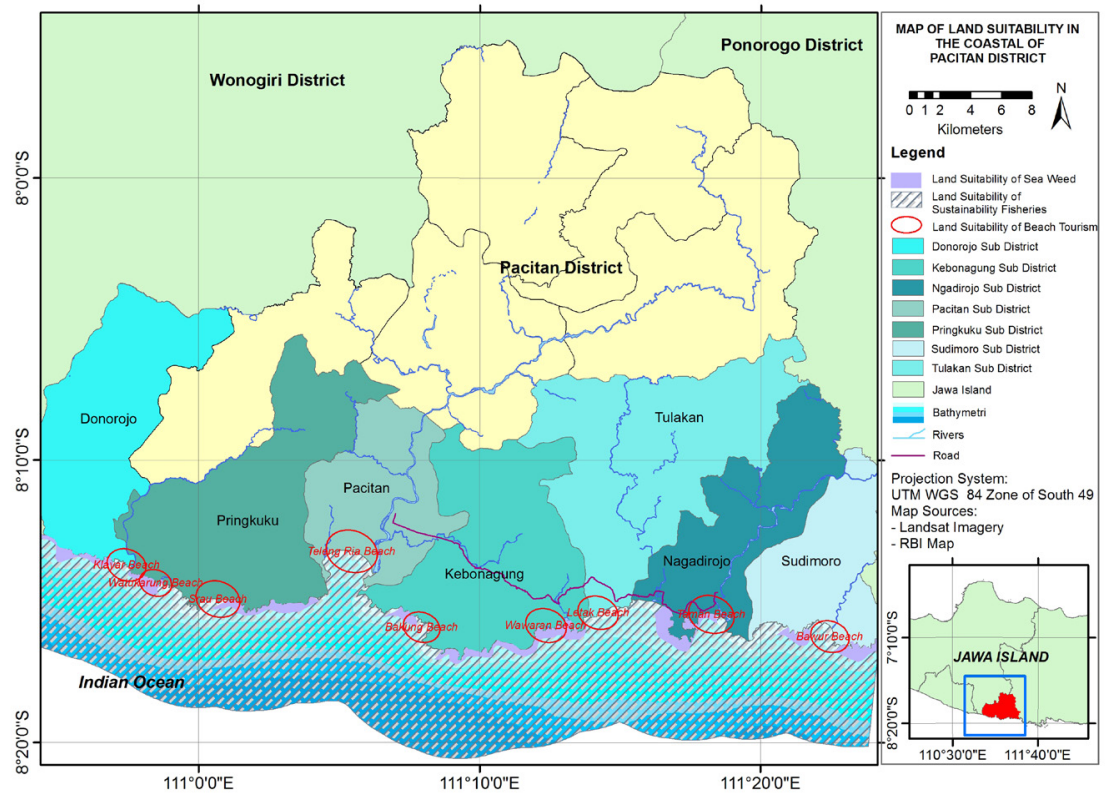

Figure 5. Map of Land Suitability of the Coastal Utilization in Pacitan District.

determined criteria, namely geomorphology and geology, ecology, and oceanography, found out that generally, the coastline of Pacitan District is improved for beach tourism and capture fisheries, in addition to seaweed cultivationin several areas (Table 4 and Fig. 5).

The beaches along the coastline of Pacitan District have wonderful geomorphology, where the geological characteristics of the rocks and oceanography add points to the beauty of the region (Figure 6). It is reasonable that the coastal areas along the coastline in Pacitan District attract huge visitors from domestic and international tourists. In 1999/2000, it was recorded as many as 557,346 tourists visited Pacitan in which 704 were international tourists (Pemkab Pacitan, 2014). However, professional management that entailed private investors and specialized promotions was shortage. In addition, the most important support should come from the government, i.e., the provision of facilities and infrastructures that should be enhanced.

Oceanographic phenomena that happening in the waters of the Indian Ocean is due to the interaction process between the ocean and the atmosphere lead to several phenomena, including the Indian Ocean 

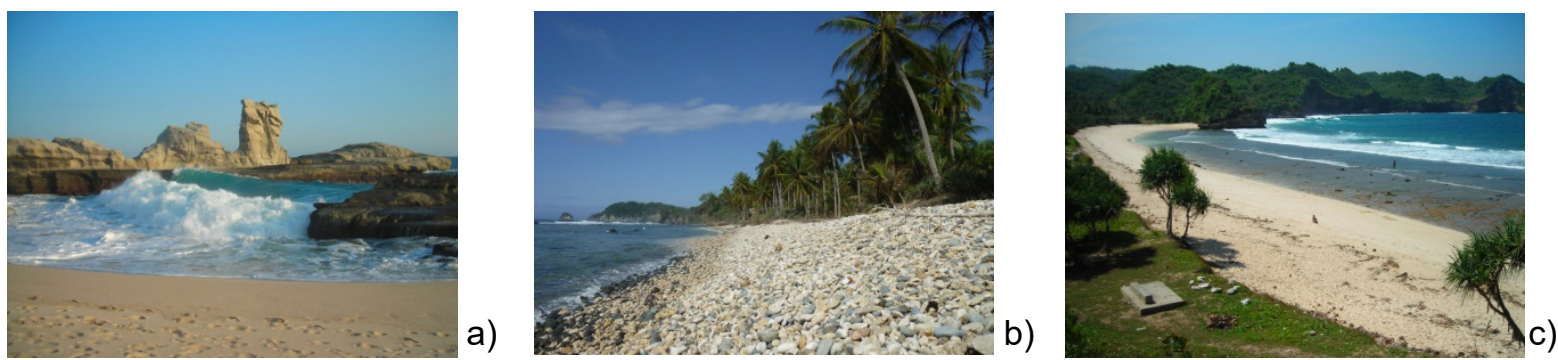

Figure 6. Prospective Spots along the Coastline of Pacitan District for Tourism-Based Activities Development. a) Klayar Beach, b) Jetak Beach, c) Srau Beach

Dipole and eddy current (Eddy \& Komalaningsih, 2008). The northern part of the Indian Ocean bordered by Asia and the southern part bordered by open waters cause the trade winds and Asia-Australia Monsoon and India-Africa Monsoon (Martono, 2009). These conditions, however, lead to the extremely high level of primary productivity in the regional waters, which directly makes this region suitable as nursery ground and important economical pelagic fish migration path (Fig. 7). Nevertheless, support from local government is essentially obliged in which most fishermen in Pacitan District were traditional ones. Shortage assistance and support including facilities and infrastructure, i.e., boat/ship capacity building, diverse fishing gears for various type of fish and different season, docks, cold storage, representative fish auctions, fuel stations for fishermen (SPBN), marine security, and effective and in-expensive regulations.

Extreme geomorphologic and oceanographic characteristics of the South Coast cause the development of seaweed cultivation in many sites in Pacitan coast was sluggish. However, based on the condition of water quality, seaweed was suitable to be cultivated in this area. In fact, seaweeds thrived naturally along the coastline of Pacitan, even though based on the analysis of land suitability, they only could be cultivated at Pacitan Bay in Pacitan Sub District and Segara Anakan Bay in Ngadirejo Sub District. Specifically in Pacitan bay, bay waters land use had been regulated in the Regional Spatial Plan (RTRW) as tourism and fishery economic center, thus, seaweed cultivationist restricted in this area. However, seaweeds were still farmed in the area of Pacitan bay, particularly in the entrance of Grindulu River estuary and Tamperan River estuary. With salinity levels of approximately $3.3 \mathrm{o} / \mathrm{oo}$, seaweed cultivation in the area of Pacitan bay was done by employing embankment model with Gracilaria species.

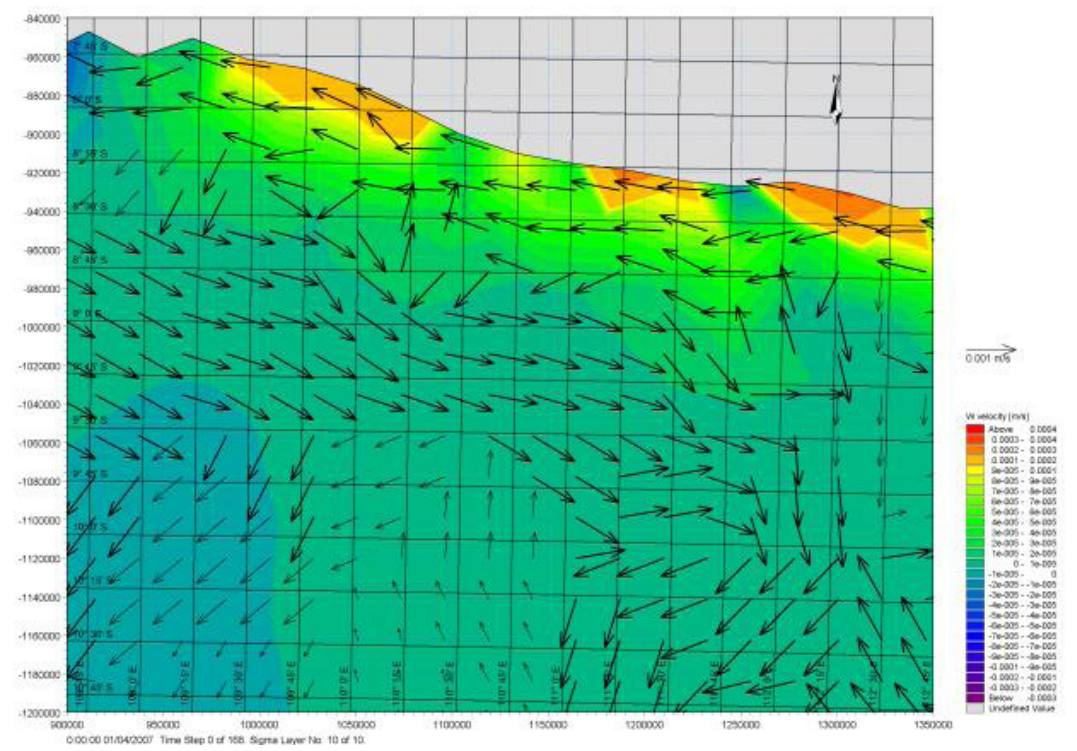

Figure 7. Vertical and horizontalmotions in ocean water bodies in Pacitan, April 2007 (red circles are demonstrated the upwelling phenomenon)(Source: Mustikasari, 2010). 
Based on the field study, the utilization and management of coastal area in Pacitan is carried out based on each region instead of coordinated by relevant agencies. Beach tourism is managed by the Tourism Office, while capture fisheries and marine aquaculture were under the responsibility of the Marineand Fisheries Office. Lack of coordination among the agencies led to impartial and overlapped spatial and concept of coastal area management. Therefore, a concept is required to integrate the entire sectors; hence, the coastal and marine management in the region will be optimum and sustainable (Bengen, 2005).

\section{The Suitability of Coastal Area Utilization and Coastal Development based on Minawisata}

The utilization sectors in coastal area particularly in Pacitan District should be supported to maintain the growth and to raise the local community's selfesteem and well-being. The encouragement should be accompanied with suitable management strategy that is integrated and oriented towards the environmental sustainability and conservation. In addition, the overlap of prevailing and potential utilization sectors should be averted. The synergy among stakeholders including government, private sector, and community is important, particularly to preserve the traditional activities or local wisdom as the heritage of a society (Bengen, 2005; Riyadi, 2004).

The concept that integrates the local community activities, both fishermen and farmers, in the development of coastal region as a tourist destination (minawisata) is one of appropriate solutions (Fig. 8) (Agus \& Azis, 2012). Minawisata is a term to define the concept of integration between the fishery activities of local communities and the tourism development activities in the coastal area.

By integrating the prevailing and potential resource development sectors, it is highly expected that the development would be more acceptable among the society and it will minimize the potential conflict (Satria, 2009). The development and management concept of an area as a tourist object should highlight the aesthetics, hygienic, and environmental safety. The tourism-based activities in coastal area simultaneously involve the participation of local communities to protect the resources existence and environmental sustainability, for example the community together to maintain coastal hygiene and using environmentally friendly fishing gear.

The tourism sector in Pacitan is prospective for further management as a tourism industry that has a capacity to compete with other regions, even foreign countries. It is reasonable since this District has diverse, peculiar, and valuable tourism objects.

By initiating the concept of minawisata, it is expected that there will be more choices and innovative destination preferences, which will eventually enhance the number of visitors to Pacitan District. Based on the analysis on the suitability of coastal area development and the development priorities in Pacitan Coast, there were 7 (seven) districts along the coastline that were prospective to be promoted for minawisata area (Table 5 and Fig. 9). Those seven districts, in fact, had been developed and targeted as coast tourism destinations. In addition, those districts also served as the source of earning for local community (fishermen), settlement, and fishery economic center. The classification of coastal utilization for minawisata development for each sub-district is described in Table 5 .
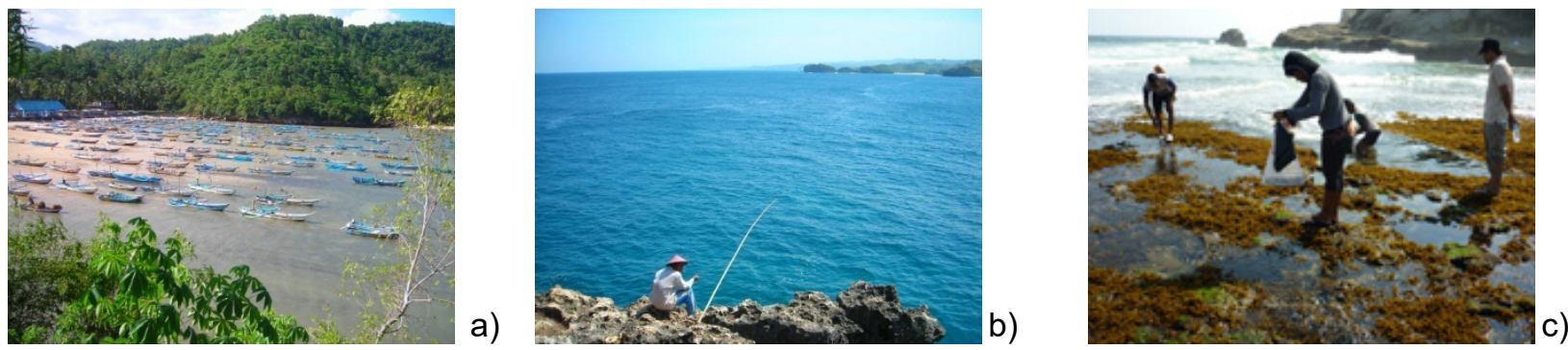

Figure 8. Prospective Minawisata activities in Pacitan Coastal Area for Tourism Promotion.a) Fishing boats waiting on the beach before departing to sea, b) Traditional fishing on the rock cliff, c) Natural seaweed harvest at the low tide. 
Table 5.

Classification of Coastal Utilization for Minawisata Development in the Coastal of Sub Districts in PacitanDistrict

\begin{tabular}{|c|c|c|c|}
\hline No. & Minawisata Area & Location & Potential type of Minawisata \\
\hline 1 & Minawisata I & Klayar Beach & $\begin{array}{l}\text { Recreational fishing at coastal cliffs and the } \\
\text { sea, swordfish/lobster fishing, sea culinary } \\
\text { and natural seaweed harvesting. }\end{array}$ \\
\hline 2 & Minawisata II & Watukarung Beach & $\begin{array}{l}\text { Recreational fishing at coastal cliffs and the } \\
\text { sea, local community settlement, seafood } \\
\text { culinary, swordfish/lobster fishing, and } \\
\text { natural seaweed harvesting. }\end{array}$ \\
\hline 3 & Minawisata III & Srau Beach & $\begin{array}{l}\text { Recreational fishing at coastal cliffs and the } \\
\text { sea,swordfish/lobster fishing, seafood } \\
\text { culinary, natural seaweed harvesting. }\end{array}$ \\
\hline 4 & Minawisata IV & Tamperan Beach & $\begin{array}{l}\text { Fishery economic center, seafood culinary, } \\
\text { sea fishing, settlement for Sirnoboyo village } \\
\text { community. }\end{array}$ \\
\hline 5 & Minawisata V & Wawaran Beach & $\begin{array}{l}\text { Recreational fishing at the sea, seafood } \\
\text { culinary. }\end{array}$ \\
\hline 6 & Minawisata VI & Tawang Beach & $\begin{array}{l}\text { Recreational fishing at the sea, seaweed } \\
\text { cultivation, seaedu-tourism, local community } \\
\text { settlement. }\end{array}$ \\
\hline 7 & Minawisata VII & Bawur Beach & $\begin{array}{l}\text { Lobster recreational fishing, eco-tourism } \\
\text { industry, seafood culinary. }\end{array}$ \\
\hline
\end{tabular}

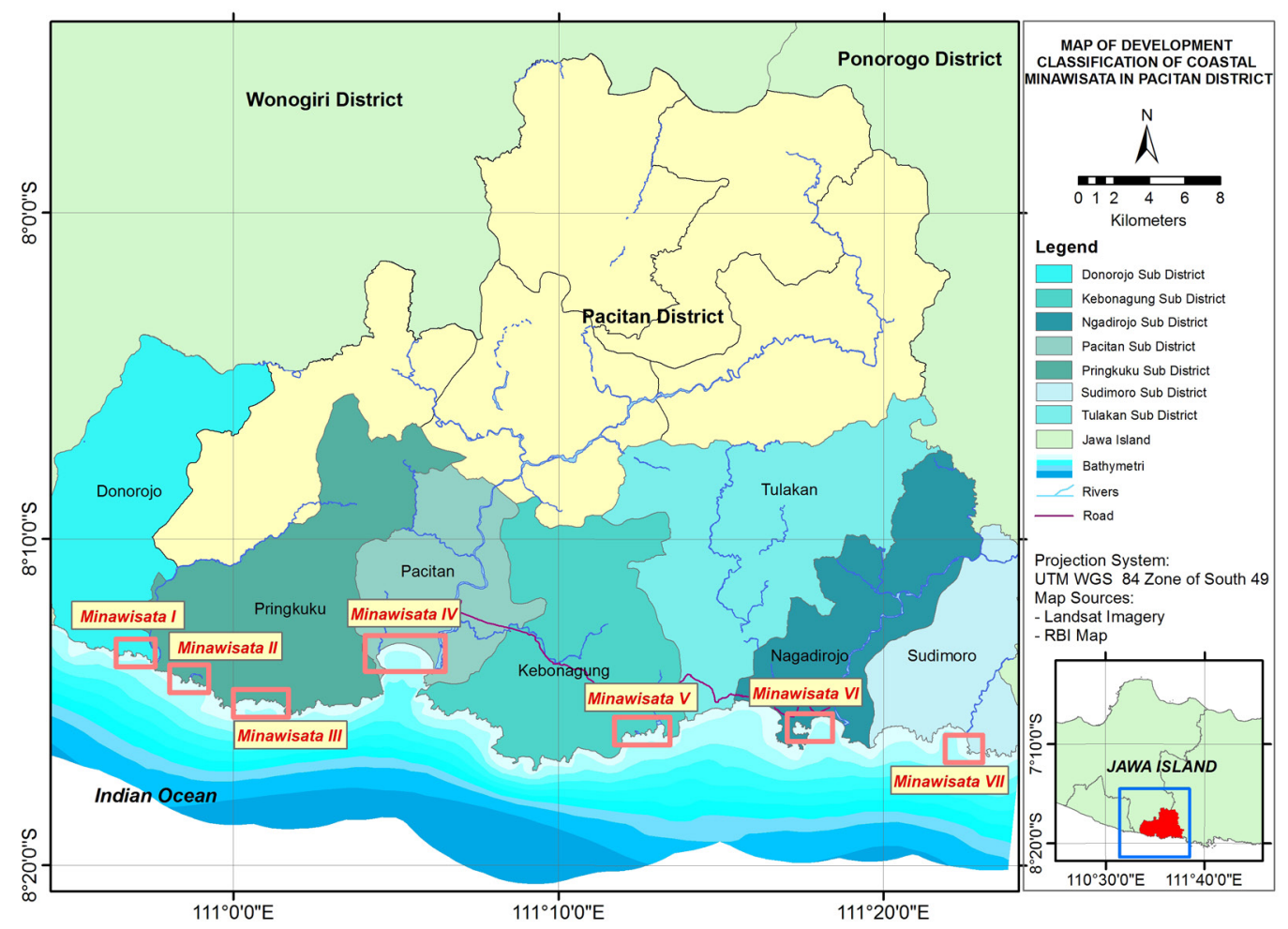

Figure 9. Map of Recommendation for Development and Management of Pacitan Coastal Area Based on Minawisata Concept. 


\section{CONCLUSION}

The findings of this study revealed that there were three main utilizations of the marine and coastal areas in Pacitan District. They were Marine Aquaculture, Capture Fisheries, and Beach Tourism. Assessment on the suitability between the coast and the sea in the seven districts in Pacitan District including Donorejo, Pringkuku, Pacitan, Kebonagung, Tulakan, Ngadirejo, and Sudimoro districts indicated that they were suitable. Thus, further development would be feasible particularly regarding with capture fisheries and beach tourism. Meanwhile, only two districts were conditionally suitable for marine aquaculture i.e Pacitan District and Ngadirejo District.

\section{ACKOWLEDGEMENTS}

This research is financially supported by National Budget Fund (DIPA) for the : Research Center for Marine \& Coastal Resources (P3SDLP), the Agency for Marine and Fisheries Research, the Indonesian Ministry of Marine Affairs and Fisheries in Fiscal Year of 2011. The authors would like to thank Dr. Budi Sulistiyo, the Director of the P3SDLP, for the acquiescence of Pacitan as the study area in 2011.

\section{REFFERENCE}

Agus, D \& Aziz, A.M. (2012). Minawisata Development of Small Islands to Support the Implementation of Blue Economy. KONAS VIII Pengelolaan Pesisir, Laut dan Pulau-pulau Kecil, Mataram 22-24 October 2012.

Akrom, M., Fahrudin, A. \& Wardiatno, Y. (2015). Suitability and Carrying Capacity of Tourism in Tanjung Pasir Coast and Untung Jawa Island. Jurnal IImu Pertanian Indonesia (JIPI), Agustus 2015 Vol. 20 (2): 141.

Aslan, L.M. (1998). Seaweed Cultivation. Kanisius. Yogyakarta

Asmawi, S. (1990). Fish Maintenance in Karamba. PT. Gramedia. Jakarta.

Bengen, D.G. (2005). Pentingnya pengelolaan wilayah pesisir terpadu berbasis kesesuaian lingkungan bagi keberlanjutan pembangunan kelautan. Persfektif keterpaduan dalam penataan ruang darat-laut. Merajut inisiatif lokal menuju kebijakan nasional. Mitra pesisir (CRMP II). Jakarta.

Dahuri, R. (1998). Kebutuhan riset untuk mendukung implementasi pengelolaan sumberdaya pesisir dan lautan secara terpadu. Jurnal pesisir dan lautan. PKSPL-IPB. Volume 1, No. 1, No. 2. P5365.

Djurjani. (1998). Concept of Mapping. On the Job Training (OJT) Concerning GIS Applications for Integrated Coastal Area Planning and Management in Ten Provinces MCMA Region. PuspicsFakultasGeografi UGM and Bakosurtanal. Yogyakarta

DJPT (Departemen Kelautan dan Perikanan Direktorat Jenderal Perikanan Tangkap). (2005). Review Detail Desain PPI Tamperan Kabupaten Pacitan. Aria Jasa, Konsultan Teknik dan Manajemen. Surabaya.

Eddy, H. \& Komalaningsih, K. (2008). Karakteristik Indian Ocean Dipole Mode di Samudera Hindia Hubungannya dengan Perilaku Curah Hujan di Kawasan Sumatera Barat Berbasis Analisis Mother Wavelet. Jurnal Sains Dirgantara Vol. 5 No. 2 Juni 2008:109-129.

Eka, N.Y., Johan, Y., \& Hartono, D. (2016). Suitability Analysis and Carrying Capacity of the Coastal Ecotourism, the Recreation Category of Laguna Beach in Merpas Village Kaur District. Journal of Enggano vol. 1, no. 1, April 2016: 97-111. Eissn: 2527-5186.

Emma, H \& Mardiana, R. (2014). Community based Ecotourism Influence the Condition of Ecology, Social, and Economic Batusuhunan village, Sukabumi. Journal of Sosiologi Pedesaan Desember 2014, hlm : 146-159.

Ihsan, Soegiyanto, H., \& Hadi, P. (2015). The development of Ecotourism Potential in Bima District. Journal of GeoEco ISSN: 2460-0768 Vol. 1, No. 2 (July 2015) Hal. $195-206$.

Kamal, E. (2005). Minawisata dan Minaindustri. Informasi Kampus. Universitas Bung Hatta. Padang.

Ketjulan, R. (2010). Daya Dukung Perairan Pulau Hari Sebagai Objek Ekowisata Bahari. Paradigma. 204.14(2): 195.

Martono. (2009). Karakteristik dan Variabilitas Bulanan Angin Permukaan di Perairan Samudera Hindia. Makara Sains, Vol. 13, No. 2, November 2009: 157-162.

Masalu, D.C. (2008). Coastal data and Information Management for integrated coastal management; the role of IODE. Elsevier. Marine olicy. 32: 544550. 
Nontji, A. (1993). Laut Nusantara. Djambatan. Jakarta.

Pemkab Pacitan. (2014). Tourism Potential and Investment in Pacitan District. http://Pacitankab. go.id. Accesed on 15 December 2014.

Rangka, N.A. \& Paena, M.( 2012). Potential and Suitability of Land Seaweed Cultivation (Kappaphycus Alvarezii) Water around the District Wakatobi Southeast Sulawesi. Jurnal IImiah Perikanan dan Kelautan Vol. 4 No. 2, November 2012.

Riyadi, D.M.M. (2004). Coastal Resource Development Policy as an Alternative for Indonesia's Future Development. Sosialisasi Nasional Program MFCDP, 22 September 2004.

Saputra, A.D \& Yulmaini. (2012). Perancangan Sistem Informasi Geografis (SIG) Pariwisata di Provinsi Lampung. Jurnal Informatika, Vol. 12, No. 2, Desember 2012.

Satria, A.( 2009). Coastal and Marine for the People. IPB Press. Bogor.

Silva, C.P., Alves, F. \& Rocha, R. (2007). The Management of Beach Carrying Capacity: The Case of Northern Portugal. Journal of Coastal Research (Proceedings of the 9th International Coastal 139. Symposium). SI 50: 135.

Sudirman, S., Agus, D., Asrul., Jaelani., Nurlian, I., Suwardi., Ahmad, I., Nisaul, M., Dietriech, G.B \& Setyo, B.S. (2012). Konsep Pengembangan Minawisata Pulau-Pulau Kecil. Direktorat Pendayagunaan Pulau-pulau Kecil, Direktorat Jenderal Kelautan, Pesisir dan Pulau-pulau Kecil, Kementerian Kelautan dan Perikanan.

Sulistijo, A \& Rachmaniar, A.K. (1996). Introduction of Types of Indonesian Seaweed. Puslitbang Oseanologi- LIPI. Jakarta.

Wiadnya, D.G.R. (2011). The Concept of Minapolitan Planning in Regional Development. Preparation Workshop for Improving the Quality of Spatial Planning in the District. 22 - 23 November 2011 in InstitutTeknologi Malang. Malang.

Yulius, Hadiwijaya, L.S., Ramdhani, M., Arifin, T. \& Purbani, D. (2013). Geographic Information Systems Applications for Marine Tourism Area Determination in Wangiwangi Island, Wakatobi District. Globe Volume 15 No. 2 Desember 2013 : $129-136$. 